\title{
Komunikasi Massa dan Sosialisasi
}

\author{
Manap Solihat
}

\section{ABSTRACT}

\begin{abstract}
The research on media impact has already been numerous and some theories of media impact overcome its doubt. Research on the media impact of socialization, however is rarely conducted since it is difficult to determine the parameters. The socializations itself is a time consuming process. The research is intended to describe behaviour pattern related to the programmes in the media namely news programme, that is to find out the response, to describe students behaviour in using the information from television, to know studens responses in waching news programme through socialization, to find out involvement (impact) of gender variable toward the habis in waching news programme. The research shows that: news programme plays a role as complementer information source for student to know politic about government board, like executive, legislative or yudicative board; students try to find information not only from one channel but also from other private-owned channels as alternative to get information; based on this research, parent friends and school environment will play important role on the level of knowledge realization about credible politic. The analisys shows that gender can influence response from students in waching news. Through students socialization, the impact of news programme, impact more to men than women. Before probing this research further, it should be noted that socialization values mentioned here are not a real political participation (for example by participating in one of the political party). The socialization is meant as an attempt to shape thought, attitude and behaviour orientations on certain values which later develop as internalization process.
\end{abstract}

Kata kunci: komunikasi massa, sosialisasi, berita, dampak, siswa

\section{Pendahuluan}

Kehidupan sosial masyarakat merupakan suatu sistem interaksi antara seseorang dengan orang lain. Interaksi dapat berlangsung teratur dan dinamis apabila terjadi proses memberi dan menerima secara positif, dalam arti hubungan yang saling menguntungkan. Lembaga negara merupakan wadah yang mengatur terjadinya proses positif tersebut. Oleh karena itu, keberlangsungan negara perlu dipertahankan dengan cara menyosialisasikan nilai-nilai yang dianut oleh negara dan masyarakat. Nilai-nilai itu tidak bersifat mutlak statis melainkan bergeser ke arah perkembangan masyarakat dan negara itu sendiri. Dengan demikian, proses sosialisasi tidak pernah berhenti.

Sosialisasi merupakan suatu proses yang panjang, baik secara sengaja atau tidak, seseorang dalam kehidupannya mengadakan suatu proses internalisasi. Nilai-nilai sosial yang ada disosialisasikan oleh generasi tua kepada generasi muda sebagai proses natural untuk menjaga kaidah sistem sosial yang berlaku. Lembaga negara yang bertindak sebagai agen sosialisasi yang menjaga transmisi nilai-nilai, baik sosial maupun politik. 
Keluarga adalah agen sosialisasi yang utama bagi anak-anak. Proses ini menentukan pembentukan orientasi berpikir seseorang, bahkan keluarga merupakan pusat pengaruh yang terbesar. Semakin seseorang tumbuh dewasa, makin banyak berinteraksi. Pada fase ini, lembaga yang paling berperan adalah sekolah dan perkumpulan dalam masyarakat, juga media massa.

Dalam masyarakat yang relatif tradisional, agen sosialisasi terbatas pada keluarga, sekolah, teman sebaya, dan perkumpulan dalam masyarakat. Seiring dengan perkembangan teknologi informasi yang menandai masyarakat modern, media massa menjadi agen sosialisasi yang utama. Dalam hal ini, bukan berarti keluarga dan lingkungan masyarakat tidak berpengaruh lagi, tetapi media massa mempunyai kekuatan besar untuk memberikan informasi yang mengarahkan pola berpikir dan berperilaku seseorang.

Kemajuan teknologi elektronik yang semakin pesat menjadikan televisi sebagai media sumber informasi yang dapat dipercaya. Samuel L. Becker bahkan menyebutnya sebagai window on many world, karena televisi menempatkan dirinya sebagai media kompleks yang dilengkapi dengan audio visual. Keberadaan televisi bagi pelajar sebagai sumber informasi yang esensial. Apalagi televisi juga banyak menyajikan acara-acara hiburan yang diminati pelajar di Indonesia. Dengan demikian, keberadaan televisi menjadi media yang penting sebagai sumber hiburan dan informasi bagi siswa sekolah dan masyarakat pada umumnya.

Jika membicarakan media televisi maka hal yang banyak menimbulkan masalah adalah dampak pesan yang disiarkan. Ketika polemik pengaruh media massa berkembang, orang mulai mencari kembali keberadaan media massa dalam kehidupan sehari-hari. Di satu saat, orang mengatakan media tidak mampu menimbulkan efek psikologis - untuk mengerahkan emosi-terlebih lagi menimbulkan perilaku yang nyata (social movement). Media tidak lebih sebagai pemantap stabilitas tatanan sosial, nilai-nilai sosial. Pada sisi lain, media dianggap mampu menciptakan tatanan sosial baru dan mampu mengadakan perubahan sosial. Terlepas dari kedua pertentangan itu, yang pasti media massa berfungsi sebagai lembaga yang dipercaya sebagai pengantar informasi dunia luar, secara perlahan mampu mensosialisasikan nilainilai dalam masyarakat. Menurut Mc.Cron (1976), "media tidak bersifat pro-sosial dan tidak pula antisosial, tetapi cenderung mendukung nilai-nilai yang telah mapan dan mungkin kelas yang berkuasa. Dengan demikian, teori yang menyatakan bahwa media menimbulkan dampak sosialisasi, sukar diragukan. (McQuail, 1987: 252).

Media massa televisi mempunyai keterbatasan dalam penyelenggaraan siarannya, karena televisi mempunyai keterkaitan erat dengan kebijaksanaan pemerintah. Hal ini bertujuan untuk mengontrol media yang menghubungkan tujuan nasional dengan aspirasi masyarakat Indonesia. Dalam rangka pembangunan bidang politik upaya yang dilakukan pemerintah dalam perspektif softwarenya, yaitu peningkatan kesadaran berpolitik dari warga negara, di antaranya; meningkatkan kesadaran politik rakyat akan kehidupan demokrasi yang bertanggung jawab dan kesadaran hidup bernegara secara teratur berdasarakan konstitusi, mengembangkan komunikasi timbal balik yang jujur antara masyarakat, antara masyarakat dengan pemerintah dan lembaga-lembaga perwakilan rakyat, pembinaan generasi muda dalam rangka perampungan proses regenerasi.

Proses kesadaran politik bangsa Indonesia merupakan hal yang penting dari pemerintah untuk memberikan pandangan baru pada masyarakat luas. Pandangan baru ini sehubungan dengan trauma politik yang dialami Indonesia, baik pada waktu Orde Lama ke Orde Baru bahkan setelah reformasi jatuhnya rezim Orde Baru. Pemerintah berkewajiban memberikan informasi dan kebijaksanaan guna menjaga suatu stabilitas politik.

Dengan langkah lebih banyak meninformasikan hasil kegiatan pembangunan dan kebijaksanaan, pemerintah melalui media televisi, sosialisasi politik dilakukan. Dalam hal ini, media televisi dipandang mampu memberikan image atau makna pembangunan politik Indonesia, sehingga media televisi merupakan agen sosialisasi yang 
Terakreditasi Dirjen Dikti SK No. 56/DIKTI/Kep/2005

penting bagi masyarakat, khususnya generasi muda untuk memperoleh nilai politik baru.

Dalam bidang politik, faktor regenerasi atau kaderisasi merupakan suatu hal yang penting guna keberlangsungan negara. Oleh karena itu, dalam proses sosialisasi politik melibatkan pemuda sebagai aset utama, yaitu sebagai aset intelektual, pemikir, dan pembaru. Titik berat pelaksanan sosialisasi politik mengacu pada sistem politik Indonesia dewasa ini.

Generasi muda memerlukan informasi sejarah dan perkembangan politik. Dengan demikian, sebagai sumber daya manusia dalam pembangunan dapat berpartisipasi, sehingga keberlangsungan negara dapat dpertahankan.

Informasi mengenai pembangunan dan halhal yang berkaitan dengan kebijaksanaan pemerintah disiarkan melalui televisi, salah satunya dalam bentuk siaran berita telah diolah dan diseleksi, sehingga dapat ditampilkan sesuai dengan tujuan negara dalam pembangunan. Siaran berita pembuatannya dilakukan secara objektif dengan ketentuan jurnalistik siaran. Begitu pentingnya penyiaran informasi ini banyak dilakukan oleh statsiun-stasiun televisi yang ada di Indonesia.

\section{Metode Penelitian}

Prosedur penelitian terdiri dari beberapa hal, yaitu: subjek penelitian, metodologi, operasionalisasi variabel, teknik pengumpulan data, dan teknik analisis data.

Populasi yang menjadi sasaran penelitian adalah siswa SMU Negeri I Kodya Bandung, dengan metode pengambilan sampel melalui purposive sampling, karena populasinya relatif homogen dan siswa dianggap homogen didasarkan pada kelas dengan mengambil sampel kelas dua dan kelas tiga, dengan anggapan bahwa kelas dua dan tiga dianggap telah dewasa dan segera memasuki dunia pendidikan tinggi, sedangkan siswa kelas satu masih masa peralihan dari jenjang pendidikan di SMP ke SMU.

Metode penelitian yang digunakan dalam penelitian ini adalah metode deskriptif yang bertujuan melukiskan secara sistematis fakta atau karakeristik populasi atau bidang tertentu secara faktual dan cermat.

Meratakan jalan untuk membuat rencana penelitian selanjutnya bahkan sampai ke eksperimental (Rakhmat, 1989:43).

Dalam penelitian ini, pengumpulan data dilakukan melalui penyebaran angket. Angket berupa daftar pertanyaan yang telah disusun sebelumnya dan dibagikan kepada responden.

Sesuai dengan metode yang digunakan, yaitu metode deskriptif, maka teknik analisis data yang digunakan adalah analisis deskriptif. Analisis deskriptif dilakukan dengan cara data yang masuk dari angket yang disebarkan kepada responden dikumpulkan, disusun, dijelaskan, dan diinterpretasikan. Analisis datanya adalah dengan menggunakan tabel-tabel.

\section{Hasil Penelitian}

Hasil penelitian ini akan menjelaskan paparan mengenai tanggapan siswa terhadap acara siaran berita SCTV, yang meliputi siaran "Liputan 6 Pagi," "Liputan 6 Siang" dan "Liputan 6 Petang." Dengan cara analisis deskriptif, yaitu meliputi tabulasi data dengan menggunakan tabel-tabel, kemudian dipaparkan, digambarkan, dan dijelaskan.

Hasil penelitian mengenai tanggapan siswa menonton siaran berita dengan sosialisasi siswa di Sekolah Menengah Umum Negeri I Bandung adalah sebagai berikut:

Jika dilihat faktor jenis kelamin, ternyata siswa perempuan lebih banyak berada pada indeks prestasi di atas rata-rata kelasnya. Namun, ternyata bahwa siswa yang paling menonjol indeks prestasinya adalah siswa laki-laki dan rata-rata pekerjaan orang tua mengindikasikan kemampuan ekonomi yang cukup, karena hanya 2 orang, orang tua siswa yang bekerja sebagai petani dan buruh. Jadi, secara ekonomi siswa dianggap tidak mengalami kendala yang cukup berarti.

Dari indikator kedekatan siswa dengan keluarganya menunjukkan juga bahwa mereka mempunyai kondisi psikologis dan sosial yang menguntungkan bagi perkembangan jiwa siswa yang bersangkutan dalam menempuh pendidikan maupun berinteraksi dengan lingkunganya, baik 
lingkungan keluarga maupun lingkungan sekolah dan lingkungan masyarakat. Siswa laki-laki juga lebih banyak mencari sumber-sumber informasi lain berkaitan dengan informasi politik melalui media massa elektronik maupun cetak.

Siaran berita SCTV cukup diminati oleh penonton kalangan pelajar, walaupun sudah banyak juga televisi swasta melakukan dan menyelenggarakan siaran berita yang beragam. Ini juga dapat menunjukkan bahwa kekuatan SCTV dalam penyebaran informasi relatif lebih dapat menjangkau wilayah yang luas dibandingkan televisi-televisi swasta lainnya yang berada di beberapa kota saja, dan bagaimanapun SCTV masih dipandang cukup penting fungsinya sebagai sumber informasi apalagi bagi masyarakat yang belum terjangkau oleh televisi-televisi swasta lainnya.

Siswa lebih banyak menonton berita pada petang hari, hal ini disebabkan biasanya segala hal berkaitan dengan sekolah sudah dapat diselesaikan pada siang harinya dan pada petang hari mereka mempunyai waktu senggang yang cukup sehingga dapat menonton siaran berita petang, sambil kumpul-kumpul dengan anggota keluarga lainnya. Siswa kadang-kadang menonton berita siang jika sempat dan sudah sampai di rumah atau tidak ada lagi kegiatan sekolah yang harus diikuti seperti kegiatan olah raga dan ekstrakurikuler lainnya.

Dilihat dari lamanya menonton, siswa lebih banyak menonton kurang dari 30 menit, karena harus segera berangkat ke sekolah dan harus berburu kendaraan di mana pagi-pagi kendaraan relatif padat penumpang dan lagi kalau pagi-pagi lebih tertuju pada kesibukan persiapan sekolah dan siswa lebih banyak menonton berita kadangkadang saja, dikarenakan mereka baru saja selesai dan tiba di rumah selepas sekolah dan itupun dilakukan jika tidak ada kegiatan lain di sekolah atau pulang cepat karena tidak hadirnya guru pelajaran pada jam terakhir jadi mereka bisa pulang cepat.

Siswa yang tidak pernah menonton berita siang lebih kecil daripada mereka yang tidak pernah menonton berita pagi dan alasannya adalah dikarenakan harus mengikuti kegiatan tambahan di sekolah, yaitu mengikuti kursus, mengikuti kegiatan olahraga, dan mengikuti kegiatan ekstrakurikuler lainnya

Siswa yang tidak pernah menonton berita petang lebih kecil daripada mereka yang tidak pernah menonton berita siang, dan alasannya adalah dikarenakan mereka sudah ada di rumah dan relatif mempunyai waktu senggang yang cukup. Biasanya pada jam tersebut dilakukan siswa sambil berkumpul dengan anggota keluarga lainnya. Mereka juga menonton sambil mempersiapkan bahan-bahan pelajaran untuk esok harinya.

Siswa laki-laki sangat sering menyaksikan berita olah raga dan sering menonton berita-berita sosial, dan kadang-kadang menyaksikan beritaberita ekonomi. Sesuai dengan minat siswa lakilaki bahwa mereka biasanya lebih banyak tertarik dengan berita-beria olah raga, maka dari hasil angket tersebut siswa laki-laki sangat sering menonton acara/berita olah raga.

Pada siswa perempuan, tingkat frekuensi menonton jenis berita tertentu, yang dikategorikan sangat sering adalah sebanyak $20 \%$ pada jenis berita mengenai pemerintahan. Kemudian yang sering menonton isi berita tertentu adalah sebanyak $46 \%$ pada jenis berita ekonomi dan kadang-kadang menonton adalah $49 \%$ jenis berita olah raga, sedangkan mereka yang tidak pernah menonton jenis isi berita tertentu rata-rata di bawah $5 \%$.

Keaktifan siswa di lingkungan tempat tinggalnya dapat meliputi mengikuti perkumpulan remaja mesjid, ikut dalam kegiatan-kegiatan sosial seperti kerja bakti membersihkan lingkungan sekitar dan kegiatan olah raga. Mereka yang tidak aktif mengikuti kegiatan OSIS (Organisasi Intra Sekolah) lebih kepada status keanggotaan sebagai anggota biasa dari OSIS karena statusnya sebagai pelajar. Kelompok ini, walaupun tidak aktif tetapi untuk acara-acara tertentu mereka tidak dapat menghindarinya seperti olah raga atau mengikuti kegiatan belajar kelompok.

Siswa laki-laki dan perempuan yang kurang aktifdalam kegiatan ekstra kurikuler masing-masing 
Terakreditasi Dirjen Dikti SK No. 56/DIKTI/Kep/2005

berjumlah 39,5\% dan 48\%, yang tidak aktif sama sekali mengikuti kegiatan ekstrakurikuler di sekolahnya masing-masing adalah 11,4\% siswa laki-laki, dan $18 \%$ siswa perempuan, adapun kegiatan-kegiatan ekstrakurikuler yang bisa diikuti siswa di sekolahnya adalah kegiatan olah raga seperti bola basket, volley ball, sepak bola, bulutangkis, tenis meja, dan atletik, kegiatan minat kesenian seperti seni musik, paduan suara, dan kepemimpinan seperti gerakan pramuka dan pecinta alam, kegiatan kerohanian seperti pengajian dan kegiatan mesjid lainnya.

Sumber otoritas politik bagi mereka, tidak saja didapat dari media televisi saja. Bahkan, pelajaran sekolah dapat merupakan sumber informasi pertama kalaupun mereka mendapatkan dari televisi dianggap sebagai informasi pelengkap saja. Apalagi jika dikaitkan dengan pelajaran tertentu yang ada kaitannya dengan tugas sekolah, baru mereka mencari informasi dari televisi atau media lainnya.

Secara keseluruhan, baik siswa laki-laki maupun perempuan, berpendapat bahwa media televisi sebagai sumber informasi tentang otoritas politik lebih banyak dari masing-masing kategori adalah pada informasi-informasi tentang eksekutif, hal ini juga sangat berkaitan bahwa kecenderungan dengan fungsi-fungsi lembaga negara yang banyak menyoroti eksekutif.

Siswa laki-laki maupun perempuan yang menyatakan kurang setuju dan tidak setuju alasan mereka bahwa selama ini yang diinformasikan oleh televisi bersifat semu dan sepihak bahwa kenyataan yang ada masih banyak hasil pembangunan yang tidak bermanfaat dan kurang memenuhi standar mutu yang bagus, sehingga sebuah proyek baru berjalan beberapa saat sudah rusak kembali. Juga tidak meratanya program pembangunan yang ada, mereka berpendapat selama ini informasi pembangunan dari Jawa lebih banyak dibanding daerah luar Jawa.

Ketidaksetujuan siswa mengenai isi siaran berita, mereka berpendapat bahwa berita-berita yang selama ini disiarkan lebih banyak meliput tentang kegiatan-kegiatan seremonial belaka, menyangkut kegiatan para pejabat negara seharihari yang lebih didominasi oleh informasi yang baik-baik saja. Sedangkan permasalahan pokok dari kesulitan bangsa ini lebih pada usaha-usaha retorika seakan-akan segera dapat teratasi padahal kenyataannya masih sangat jauh dari harapan.

\section{Televisi sebagai Agen Sosialisasi}

Jika terjadi suatu fenomena sosial (yang bersifat negatif) yang berhubungan dengan dampak media, maka khalayak dengan cepat mengklaim bahwa media adalah penyebab terjadinya ketidakseimbangan atau kegaduhan dalam masyarakat tertentu.

Banyak asumsi yang menguatkan bahwa media telah gagal memenuhi harapan khalayak, sehingga lebih banyak menimbulkan frustrasi. Tetapi, sebagian kelompok masyarakat - yang sebagian besar berstatus sosial tinggi mendapatkan dan merasakan manfaat media, sehingga dapat lebih bersifat optimis pada media.

Media berbentuk suatu institusi yang berada dalam suatu sistem sosial, sehingga media merupakam alat bantu yang utama bagi interaksi sosial. Terlebih lagi dalam suatu sistem masyarakat modern.

Dalam keberadaan tersebut media berkaitan erat dengan struktural dalam masyarakat (struktur pemerintah). Oleh karena itu, media selalu berfungsi sebagai kontrol sosial dan juga alat bantu untuk menstabilkan tatanan struktur, dalam arti membantu memberikan informasi kebijaksanaan nilai-nilai yang dianut struktur pemerintah maupun masyarakat.

Media dengan ketidakberdayaannya tergantung pada nilai sistem sosial yang dianut oleh sistem pemerintahan. Dengan demikian, media kurang memiliki kebebasan - dalam arti positif - untuk menjalankan fungsi sebagai kontrol sosial. Teori dampak media, yaitu teori ketergantungan, banyak mengulas mengenai ketergantungan media pada sistem sosial tertentu dan mempunyai efek tertentu pula. Dengan kata lain, dampak media sangat berkaitan dengan sistem politik suatu negara dan sistem nilai dalam suatu masyarakat.

Dari sekian banyak teori yang menjelaskan dampak media, maka teori sosialisasi yang mengasumsikan media sebagai agen sosialisasi 
tidak diragukan lagi. Walaupun sosialisasi terjadi dalam proses yang memerlukan jangka waktu yang panjang. Dengan cara sosialisasi inilah kelanggengan sistem dapat dijaga.

Dampak sosialisasi yang merujuk pada generasi yang lebih muda, dapat dijadikan suatu pegangan oleh suatu negara untuk mempertahankan ideologi, Di Indonesia sehubungan dengan trauma politik yang pernah terjadi pada waktu pemerintahan Orde Lama, sangat perlu menanamkan nilai-nilai baru tentang ideologi negara pada generasi baru (setelah angkatan 1966), sehingga generasi selanjutnya dapat membentuk orientasi pengetahuan, sikap, dan perilaku politik yang sesuai dengan tujuan ideologi negara Pancasila. Akibat yang lebih jauh, dapat terciptanya suatu komitmen dalam bentuk parsipasi pembangunan.

Media yang paling dekat dengan generasi muda - khususnya siswa sekolah - yaitu televisi yang memiliki sifat-sifat lebih dibanding dengan media lain, misalnya adanya audio dan video yang diolah dalam bentuk seni. Oleh karena itu, media televisi dapat menjadi agen sosialisasi yang efektif bagi siswa sekolah sebagai generasi penerus.

Dengan informasi melalui berita televisi, pemerintah atau negara dapat memberikan suatu orientasi pengetahuan, sikap dan perilaku pilitik yang sesuai dengan idiologi Pancasila. Informasi tersebut lebih banyak menyiarkan informasi pembangunan dan kegiatan pemerintahan (ekskutif, legislatif, dan yudikatif).

Dalam mengakaji dampak media massa sebagai agen sosialisasi yang mampu memberikan nilai-nilai pada khalayaknya, tidak dapat mengabaikan pengaruh lembaga lain yang mempunyai interaksi lebih banyak dengan generasi muda (siswa sekolah). Lembaga lain tersebut adalah keluarga, lingkungan sekolah dan teman sebaya. Karena waktu berinteraksi lebih banyak dengan keluarga, sekolah, maupun teman sebaya dari pada menonton televisi. Faktor pengaruh inilah yang selama ini masih meragukan bahwa media massa mampu menjadi agen sosialisasi bagi khalayaknya.

Dengan suatu metode penelitian ilmiah diharapkan dapat memperoleh kerangka pemikiran mengenai dampak media pada sosialsasi. Karena, ternyata media mampu menimbulkan dampak sosialisasi maka informasi yang disiarkan melalui siaran berita hendaknya hati-hati dan selektif. Besar kemungkinannya bahwa dampak siaran berita dapat menimbulkan kesadaran yang palsu bagi khalayak, sehingga komitmen yang ingin dicapai, yaitu untuk berpartisipasi, tidak dapat terwujud. Oleh sebab itu, keterlibatan struktur pemerintah dan negara dalam pemeliharaan institusi media haruslah positif, dalam arti tidak hanya menyiarkan kepentingan elit negara, tetapi juga khalayak yang buta akan politik yang seringkali terjadi pembodohan orientasi khalayak.

Berdasarkan hasil analisis korelasi parsial pengaruh institusi lain cukup besar, orang tua dan sekolah. Oleh karena itu, orang yang terlibat di dalam keluarga dan sekolah - orang tua, guru - seharusnya mendidik anak untuk berpikir kritis, kreatif, dan sehat, guna menumbuhkan sosialisasi yang positif. Jika dampak suatu media diasumsikan kurang baik, maka anak (generai muda) dapat mengantisipasi lebih awal. Paling tidak, kesadaran pengatahuan politik lebih baik ditumbuhkan pada lingkungan yang dapat dipercaya oleh anak. Dalam hal ini, orang tua dan guru memegang peranan penting.

Perkembangan masyarakat Indonesia pada dasawarsa terakhir sedang menuju pada masyarakat modern. Dalam hal ini, keberadaan suatu media sangat penting. Jika tidak, akan tertinggal oleh informasi luar dan akan terjadi keterbelakangan dalam segala hal. Karena informasi mempunyai kekuatan dalam segala bidang kehidupan. Dengan rendahnya terpaan informasi pada siswa (dari hasil penelitian) - yaitu frekuensi menonton berita rendah, lamanya juga rendah menggambarkan kepada kita bahwa siswa harus lebih banyak megikuti informasi atau berita dari media massa, baik cetak maupun elektronik. Dengan demikian dapat diharapkan mereka menjadi generasi yang knowledgeable terhadap informasi luar, khususnya dalam hal informasi politik, sehingga dapat memengaruhi keputusan suatu struktur atau sistem sosial dan dapat menjadi subjek penggerak perubahan sosial. 


\section{Penutup}

Dengan suatu metode penelitian ilmiah diharapkan dapat memperoleh kerangka pemikiran mengenai dampak media pada sosialisasi. Hasil penelitian ini secara umum menjelaskan adanya pengaruh antara menonton siaran berita dengan sosialisasi (politik) siswa. Untuk lebih jelasnya, dapat disimpulkan sebagai berikut:

(1) Siaran berita SCTV berperan sebagai sumber informasi komplementer bagi siswa sebagai sumber informasi politik, baik pengetahuan mengenai lembaga-lembaga negara seperti eksekutif, legislatif, dan yudikatif.

(2) Siswa mencari informasi tidak hanya melalui satu media televisi saja, apalagi dengan banyaknya televisi-televisi swasta lainnya, menjadikannya banyak pilihan dalam pencarian informasi.

(3) Peran dari orang tua, teman sebaya, dan lingkungan sekolah, akan sangat berperan penting pada tarap kesadaran pengetahuan tentang politik yang terpercaya.

(4) Faktor jenis kelamin memengaruhi tanggapan siswa dalam menonton siaran berita dengan sosialisasi siswa. Pada jenis kelamin laki-laki, tingkat terpaan siaran berita lebih tinggi daripada jenis kelamin perempuan.

Dengan demikian, pengaruh menonton siaran berita dengan sosalisasi politik siswa dapat dikatakan bersifat melengkapi karena masih banyak faktor lain. Variabel lain tersebut mewakili indikator suatu lembaga agen sosialisasi. Maka, jika kita mengatakan ada pengaruh antara menonton siaran berita dengan sosialisasi politik siswa, tidak dapat mengabaikan begitu saja variabel luar yang mungkin berpengaruh pada hubungan tersebut.

\section{Daftar Pustaka}

Alfian. 1991. Komunikasi Politik dan Sistem Politik Indonesia, Jakarta: Gramedia.

Fisher, Aubrey, 1993, Teori - Teori Komunikasi, diterjemahkan oleh Y.Ardi dan Gabriel, Jakarta: Erlangga.

Kantaprawira, Rusadi, 1986, Sistem Politik Indonesia, Jakarta: Rajawali.

McQuail, Dennis, Windahl Sven, 1985, ModelModel Komunikasi, diterjemahkan oleh Agus Dharma, Aminuddin, Jakarta: Erlangga.

1987, Teori Komunikasi Massa, Jakarta: Uni Primas.

Nimmo, Dan, 1989, Komunikasi Politik, Jilid I, Bandung: Remadja Karya.

Nimmo, Dan, 1989, Komunikasi Politik, Jilid II, Bandung: Remadja Karya.

Rakhmat, Jalaluddin, 1987, Psikologi Komunikasi, Bandung: Remadja Karya. 1989, Metode Penelitian Komunikasi, Bandung: Remadja Karya.

Wright, Charles R., 1986, Sosiologi Komunikasi Massa, diterjemahkan oleh Lilawati dan Jalaluddin, Bandung: Remajda Karya.

Varma, S.P., 1990, Teori Politik Modern, diterjemahkan oleh Yohanes Kristiarto, Jakarta: Rajawali.

www:// SCTVnews.com 
